\title{
KLAIPEDDOS RAJONO GYVENTOJŲ KORUPCIJOS SUVOKIMO IR PATIRTIES KAITA PANDEMIJOS SĄLYGOMIS
}

\author{
Ilvija Pikturnaité1, Jurgita PaužUoliené², Robertas Kavolius ${ }^{3}$ \\ Klaipėdos valstybinè kolegija (Lietuva)
}

\begin{abstract}
ANOTACIJA
Pasaulinė pandemija ir būtinybė imtis atsako veiksmų sukuria palankią terpę korupcijai, silpnina jos prevencijos priemones bei keičia visuomenės moralines nuostatas. Nacionaliniai tyrimai atskleide prastėjančią korupcijos prevencijos situaciją, piliečių ketinimą imtis neteisètu veiksmų sprendžiant savo problemas. Straipsnyje pristatomi tęstinio Klaipėdos rajono savivaldybeje atlikto tyrimo rezultatai, leidžiantys ịvertinti gyventojų korupcijos suvokimo ir patirties kaitą pandemijos sąlygomis. Nors vis daugiau Klaipédos rajono gyventojų suvokia korupcijos grèsmę ir žalą, ištirta, kad pateisinančiujų korupciją, kaip galimą problemos sprendimo būdą, dalis vis dèlto padidèjo. Respondentų nuomone, korupcija labiausiai paplitusi: medicinos ịstaigose, teisme, žemètvarkoje. Tyrimo dalyviai nurodè šiek tiek dažniau davę kyšius ịvairiems subjektams, dažniausia - medicinos įstaigų darbuotojams. Nors gyventojai mažiau pastebi užuominų ir kyšio prašymų, tačiau dažniau patys apsisprendžia duoti kyši. Be to, daugiau respondentų nurodè ketinantys ir ateityje duoti kyšį prireikus spręsti problemas.

PAGRINDINIAI ŽODŽIAI: korupcija, savivaldybès, korupcijos prevencija, gyventoju požiūris.
\end{abstract}

JEL KLASIFIKACIJA: D73, H79, K40.

DOI: http://dx.doi.org/10.15181/rfds.v34i2.2252

Ivadas

Korupcija dažniausia apibrěžiama kaip „piktnaudžiavimas patikèta valdžia siekiant asmeninès naudos“ (Transparancy international, 2021a). Gana vaizdžiai korupcijos esmę apibūdino J. Lewis'as (2017), kaip valdžios ir godaus elgesio pasekmę netinkamo valdymo kontekste. Daugelis autorių akcentuoja šio reiškinio paplitimą. E. Dimant'o, G. Tosato'o (2018) teigimu, korupcija yra sudètingas socialinis reiškinys, pasireiškiantis visais visuomenès lygmenimis. Ji yra pasaulinio masto ir pasireiškia įvairiomis formomis visų tipų organizacijose (Kohler, Dimancesco, 2020). Korupcijos reiškinị analizuojančioje mokslinėje literatūroje (Bowman, Gilligan, 2007; Iqbal, Seo's, 2008; Ackerman, 2001; Graycar, Sidebottom, 2012; Ackerman, Truex, 2012; Slamkov, Bilalli-Zendeli, 2016; Kozlowski, Kozlowska, Swirska, 2016; Mackey, Vian, Kohler 2018) ir nacionaliniuose teisès aktuose (LR Seimo nutarimas „Dèl LR nacionalinès kovos su korupcija 2015-2025 m. programos patvirtinimo“, 2015) pažymimas neigiamas korupcijos visuminis poveikis šalims bei tam tikroms visuomenès gyvenimo sritims. Akcentuojamas didžiulis korupcijos poveikis ekonomikos ir visuomenès plètrai (Dimant, Tosato, 2018; Kohler, Dimancesco, 2020), ji pažeidžia teisinę valstybę (Begovic, 2005). J. C. Kohler (2011),

Ilvija Pikturnaitè - docentè, daktarè (socialiniai mokslai), Klaipèdos valstybinès kolegijos Verslo administravimo katedra Moksliniai interesai: viešasis administravimas, personalo valdymas, strateginis valdymas

El. paštas: i.pikturnaite@kvk.1t

Tel. +370674364 43

2 Jurgita Paužuolienè - docentè, daktarè (socialiniai mokslai), Klaipėdos valstybinès kolegijos Verslo administravimo katedra Moksliniai interesai: darnus ir socialiai atsakingas verslo vystymas, organizacinė kultūra, valdymo problemos ir tyrimai El. paštas: j.pauzuoliene@kvk.lt Tel. +370621 41916

Robertas Kavolius - lektorius, Klaipėdos valstybinès kolegijos Verslo administravimo katedra

Moksliniai interesai: sociologija ir socialiniai tyrimai

El. paštas: r.kavolius@kvk.1t

Tel. +37065090905 
J. C. Kohler, D. Dimancesco (2020) teigia, kad korupcija skatina nelygybę, nes iškreipia išteklių paskirstymą ir sudaro kliūčių visuomenès sveikatos paslaugų ir prekių sklaidai, dẻl ko labiausiai nukenčia neturtingieji. Sveikatos sektoriaus korupcija tiesiogiai stabdo pažangą, siekiant visuotinės sveikatos aprèpties, slopindama žmonių galimybes naudotis kokybiškomis sveikatos paslaugomis (Mackey, Vian, Kohler, 2018). Pasaulinės pandemijos COVID-19 akivaizdoje korupcijos reiškinys ir su tuo susijusios problemos tampa dar aktualesnès. Nacionalinè ir užsienio šalių vyriausybès bei tarptautinès organizacijos (United Nations, COVID-19 response, 2020; World Justice Project, 2021) pranešimuose apie COVID-19 dažnai analizuoja esamas ir potencialias situacijas dẻl ekonomikos, socialinès ir švietimo krizès, medicininių priemonių bei įrangos trūkumo, šios sistemos fizinio pervargimo. Pavyzdžiui, Jungtinès Tautos (United Nations Office of Drugs and Crime, 2020) pranešè apie Ramiojo vandenyno salų patiriamus socialinius ir ekonominius iššūkius (bedarbystę, prekių trūkumą, kainų augimą), kurie pasireiškẻ anksčiau nei salyne ištirti pirmieji COVID-19 atvejai; pranešime akcentuojamas medicinos sistemos nepasirengimas, medicinos infrastruktūros bei intensyvios terapijos vietų trūkumas. Tarptautinès organizacijos (United Nations, 2020), mokslininkai (Chakraborty, Mait, 2020; Šimanskienė, Paužuolienè, Staškevičius, 2020) identifikuoja COVID-19 pandemijos poveikį visuomenès socialiniu ir psichologiniu lygmenimis. Ekonominis nestabilumas, smurtas artimoje aplinkoje, kasdienės rutinos nebuvimas ir priverstinis jos keitimas, ribotos galimybės judèti neabejotinai neigiamai veikia visuomenès psichinę sveikatą bei socialinius igūdžius (Šimanskienè, Paužuolienè, Staškevičius, 2020). O patiriama pagrịsta baimè dèl savo ir artimujų sveikatos gali lemti moralinių nuostatų kaitą.

Akivaizdu, kad pasaulinė pandemija ir būtinybė imtis atsako veiksmų silpnina daugelio šalių korupcijos prevencijos priemonių veikimą (United Nations Office of Drugs and Crime, 2020; World Justice Project, 2021), esant būtinybei įsigyti prekių nesilaikant viešujų pirkimų įstatymų ir net nesiderant dẻl jų kainos, kovoti dèl sunkiai prieinamų išteklių (medicinos priemonių ir ịrangos, šios srities darbuotojų). Tuo tarpu daugelis korupcijos prevencijos vykdymo mechanizmų dèl nepaprastosios padèties sustabdyti. Tokios situacijos leidžia atsirasti naujoms korupcijos formoms, o korumpuotiems asmenims pasinaudoti susidariusia situacija papirkinejjant ar gaunant kyšius, sudarant susitarimus nepagristomis kainomis, naudojantis tarnybine padètimi gaunant medicininę pagalbą ar skiepus, reikalaujant mokèti už viešąsias bei jau apmokètas paslaugas, grobstant paramą ir kt.

Nacionaliniai statistinès informacijos šaltiniai kurị laiką identifikavo neryškius teigiamus antikorupcinès aplinkos pokyčius per ilgesnị laikotarpi (Lietuvos Respublikos specialiujų tyrimų tarnybos (toliau - LR STT) veiklos ataskaita, 2018; Lietuvos korupcijos žemèlapis, 2018). Kasmet atliekamos gyventojų, įmonių vadovų ir valstybės tarnautojų apklausos „Lietuvos korupcijos žemėlapis“ rezultatai atskleidè ilgametes visuomenės korupcinès patirties mažèjimo tendencijas: 2018 metais 12 proc. gyventojų nurodè, kad jie per pastaruosius 12 mėnesių bent kartą davè kyšį (2016 m. - 16 proc.). Kyla natūralus klausimas, ar viešojoje erdvejje sklindanti informacija apie išteklių trūkumą ir kitų asmenų bei organizacijų korupcinę veiklą, valdžios atstovų teisinimasis dẻl būtinybès įsigyti ribotus išteklius keičia visuomenès požiūrị i korupciją, nuostatas vykdyti ir toleruoti korupcinę veiklą? 2020 m. „Transparency International“ (TI) Korupcijos suvokimo indekso (KSI) tyrime Lietuvos balas išliko nepakitęs (palyginus su 2019 m. duomenimis) (Transparency international, 2020). Lietuvai skirti 60 balų iš 100 galimų ir 35 vieta 180 šalių sąraše, ji tarp Europos Sajungos (ES) valstybių užima 14-ą vietą.

Remiantis „Lietuvos korupcijos žemėlapio“ 2020 m. duomenimis, korupcija įvardijama kaip labai rimta problema, ji užima penktą vietą tarp kitų aktualių problemų (po mažų atlyginimų, sveikatos apsaugos problemų, didelių kainų ir bedarbystès). Tyrimas atskleidè ir tai, kad dalis piliečių ne visada ją atpažista, pvz.: 31 proc. apklaustujų mano, kad atsilyginimas gydytojui po operacijos ar procedūros nèra korupcinė veikla; 25 proc. - kad naudojimasis tarnybiniu automobiliu nepriskiriamas korupcijai (Lietuvos korupcijos žemèlapis, 2020; 2021). 37 proc. gyventojų mano, kad asmenys atsidèkoja pinigais po sėkmingai atliktos operacijos ar procedūros; 35 proc. - kad asmenys ịsidarbina ị valstybės instituciją pasinaudoję pažintimis. Dažniausia apklausti gyventojai nurodè, kad labiausiai Lietuvoje paplitęs nepotizmas (74 proc.), politinių partijų narių protegavimas (66 proc.), palankių įstatymų, naudingų paskiroms grupėms, priėmimas (58 proc.). $2020 \mathrm{~m}$. gyventojų nuomone, labiausiai korumpuotos institucijos yra: gydymo ịstaigos / sveikatos apsauga - 51 proc., teismai - 37 proc. ir Seimas - 33 proc. (Lietuvos korupcijos žemèlapis, 2020; 2021). Palyginus su $2019 \mathrm{~m}$. „Lietuvos korupcijos žemėlapio“ duomenimis, daugeliu atvejų nurodomas didesnis konkrečių korupcijos 
formų paplitimas. Tyrimo dalyviai 2020 metais daugeli institucijų vertino kaip labiau korumpuotas: 9 proc. tyrimo dalyvių per pastaruosius 12 mèn. davè kyšș; 23 proc. - davé per pastaruosius penkerius metus. 71 proc. gyventojų ir net 24 proc. valstybės tarnautojų mano, kad kyšis padeda spręsti problemas. Šiek tiek padidejo asmenų, ketinančių duoti kyšį (18 proc.), dalis. Didelè dalis gyventojų nurodè, kad pasinaudotų giminystès ryšiais (33 proc.) ir pažintimis (36 proc.), siekdami įsidarbinti viešajame sektoriuje ar norèdami, kad jiems greičiau ir kokybiškesnès paslaugos būtų suteiktos (atitinkamai 31 proc. ir 38 proc.). Palyginus su 2019 m., šių rodiklių reikšmès padidèjo. Nors „Lietuvos korupcijos žemėlapyje“ respondentai apie pandemijos poveikį neklausiami, tyrimo duomenys leidžia daryti prielaidą, kad pandemija korupcinèms veikloms sukuria palankią terpę ir keičia visuomenès požiūrị ị šị reiškinị. Mokslininkai (Ackerman, 2002; Iqbal, Seo, 2008; Ackerman, Truex, 2012; Kozlowski, Kozlowska, Swirska, 2016) jau yra konstatavę neigiamą korupcijos poveikị piliečių pasitenkinimui ir pasitikejjimui valdžia, jos institucijomis ir lyderyste.

Piliečiai savo kasdieniuose reikaluose dažnai susiduria su vietos valdžia, tad vietos savivaldos institucijų teisèta ir skaidri veikla tiesiogiai susijusi su asmenų korupcine patirtimi ir požiūriu ị korupciją. Remiantis „Lietuvos korupcijos žemėlapio 2020“ (2021) tyrimo duomenimis, miestų ir rajonų savivaldybės laikomos vienos labiausiai korumpuotų institucijų Lietuvoje. Lietuvos gyventojai mano, kad korupcija labiausiai paplitusi savivaldybių viešujų pirkimų (45 proc.), statybos (32 proc.), žemės duomenų, teritorijų planavimo skyriuose. Savivaldybių skaidrumo tyrimo $2018 \mathrm{~m}$. duomenys atskleidžia šios srities skirtumus šalies mastu: LR savivaldybès pasiskirsto skalèje nuo 39 iki 79 proc. (100 proc. skalè). Taigi tikslinga detaliau stebèti korupcinę situaciją konkrečioje savivaldybëje. Todèl šiame straipsnyje pristatomas Klaipėdos rajono savivaldybeje atliktas tęstinis gyventojų korupcijos suvokimo ir patirties tyrimas.

Klaipėdos rajono savivaldybės administracija, vadovaudamasi Lietuvos Respublikos Korupcijos prevencijos įstatymu (2002), Lietuvos Respublikos nacionaline kovos su korupcija 2015-2025 metų programa, rengia Korupcijos prevencijos programą bei tiria gyventojų požiūrị i korupciją bei korupcinę patirtį. $2016 \mathrm{~m}$., 2018 m. ir 2020 m. Klaipėdos rajono savivaldybejje atliktas kartotinis tyrimas, leidžiantis ịvertinti gyventojų korupcijos suvokimo ir patirties kaitą. Toks tyrimas aktualus Klaipėdos rajono ir kitų savivaldybių administracijos specialistams bei politikams priimant tikslingus korupcijos prevencijos sprendimus.

Tyrimo objektas - Klaipedos rajono gyventojų korupcijos suvokimo ir patirties kaita.

Tyrimo tikslas: įvertinti Klaipėdos rajono gyventojų požiūrio ị korupciją ir korupcinès patirties kaitą pandemijos sąlygomis.

Tyrime keliami šie probleminiai klausimai: kaip keičiasi gyventojų korupcijos ir jos priežasčiu suvokimas; kaip kinta Klaipėdos rajono gyventojų korupcinė patirtis pandemijos sąlygomis?

Tyrimo metodai: mokslinès literatūros ir teisès aktų analizė, Klaipėdos rajono gyventojų anketinè apklausa, duomenų apdorojimas SPSS programa, anketinių apklausų duomenų lyginamoji analizė.

\section{Tyrimo metodologija}

Tyrimo populiaciją sudaro 30406 Klaipèdos rajono gyventojai (t. y. 18 metų ir vyresni asmenys, kurių gyvenamoji vieta deklaruota Klaipédos rajone [Oficialios statistikos portalas 2021]). Minimalus galimas respondentų skaičius (kai tikimybè - 95 proc., paklaida - 10 proc.) apskaičiuotas, taikant V. Paniot'o imties tūrio formulę, taip pat atsižvelgiant ị tyrimo tikslą, tyrimo populiacijos savybes, siekiamų gauti duomenų tikslumą ir klausimyno charakteristikas (Bryman, 2016; Pallant, 2016), yra 96 Klaipedos rajono gyventojai.

Duomenims surinkti taikytas anketinès apklausos metodas, naudojant iš anksto parengtą standartizuotą klausimyną, kuris sudarytas atsižvelgiant ị Klaipėdos rajono savivaldybės rekomendacijas. Respondentams atrinkti taikyta netikimybinè kriterinė atranka (Kardelis, 2009; Bryman, 2016). Tyrimas atliktas tiesioginiu ir nuotoliniu būdais Klaipėdos rajono savivaldybès teritorijoje $2020 \mathrm{~m}$. spalio, lapkričio mèn. Tyrimo eigą koregavo ir lëmé Lietuvoje paskelbtas karantinas. Iki jo paskelbimo tyrimas Klaipėdos rajone vyko tiesiogiai tyrejams susitinkant su respondentais. Paskelbus karantiną visoje Lietuvoje tyrimas Klaipėdos rajone tęstas nuotoliniu būdu. Kvietimas-prašymas dalyvauti tyrime išsiųstas 336 elektroninio pašto adresais ị Klaipėdos rajono viešąsias institucijas ir verslo įmones, patalpintas Klaipėdos rajono savivaldybės, Klaipėdos rajono bendruomenių feisbuko paskyrose, išsiųstas Klaipėdos rajono Trečiojo amžiaus universiteto koordinatoriui ir kt. 
Tyrimo etika. Atliekant tyrimą laikytasi šių tyrimo etikos principų: apsaugos, slaptumo (anonimiškumo ir konfidencialumo), geranoriškumo, universalumo, reikšmingumo, pagarbos asmens orumui, teisingumo, teisès gauti tikslią informaciją (Kardelis, 2009). Tyrimo etika apima šio tyrimo bendruosius parametrus (imties dydis, imties atranka, duomenu rinkimas, apibendrinimas ir kt.). Vadovaujantis etikos principais apsvarstytos visos tyrimo eigos alternatyvos, numatant jų galimybes ir grèsmes, pasirinkta tinkamiausia tyrimo eiga.

Tyrimo duomenų analizė atlikta taikant socialiniams tyrimams skirtą statistikos programą SPSS 26.0. Klausimyno vidiniam patikimumui nustatyti apskaičiuotas kiekvienos klausimų grupès Cronbach'o alfa koeficientas. Taikyto klausimyno koeficientai kinta intervale nuo 0,677 iki 0,889 (tai rodo aukštą vidinį skalès patikimumą). Grafinè analizè atlikta skaičiuokle Ms Excel. Atliekant duomenų analizę skaičiuotas atsakymų pasiskirstymas (procentais). Ranginiams kintamiesiems skaičiuotas vidurkis. Statistiškai reikšmingiems skirtumams tarp paskirų respondentų grupių nustatyti taikyti neparametriniai Kruskal-Wallis'o ir chi kvadrato kriterijai.

Tyrimo respondentų demografinès charakteristikos. $2020 \mathrm{~m}$. tyrime dalyvavo 116 respondentų (2018 m. - 146). 2020 m. tyrime moterys sudare 76,7 proc. apklaustujų. Aktyviau i tyrimą ịsitraukè dirbantys viešajame sektoriuje $(49,1$ proc.), dirbantys privačiame sektoriuje $(32,8)$ ir besimokantys / studijuojantys asmenys (14,7 proc.). 31 proc. respondentų nurodè, kad jie yra $41-51 \mathrm{~m} ., 21,6$ proc. $-52-62 \mathrm{~m}$., 20,7 proc. $-30-40$ m., 18,1 proc. - 18-29 m. Mažiausią respondentų grupę sudare vyresni nei 62 metų asmenys ( 8,6 proc.). Tad atliekant tolesnę analizę jų atsakymai bendrinti su 52-62 m. respondentų grupe.

\section{Gyventojų požiūrio i korupcijos reiškinị kaitos apžvalga}

Siekiant ịvertinti Klaipėdos rajono gyventojų požiūrị i korupciją, respondentams pateikti 5 teiginiai, kuriuos jie galèjo ịvertinti pagal 3-ų balų skalę (1 - nesutinku; 2 -iš dalies sutinku; 3 -sutinku). Remiantis tyrimo rezultatais galima teigti, kad vyrauja neigiamas respondentų požiūris ị korupciją (1 lentelè). 86,2 proc. tyrime dalyvavusiujų sutinka, kad ji iškreipia sąžiningą konkurenciją, verslo sąlygas ir mažina ekonomikos augimą. 84,5 proc. apklaustujų sutinka, kad korupcija pažeidžia žmogaus teises, iškreipia socialinị teisingumą ir žaloja visuomenès moralę. 82,8 proc. respondentų mano, kad korupcija kelia grẻsmę demokratijai ir valstybei. Kiek mažiau tyrimo dalyvių sutinka su tuo, kad už korupcinio pobūdžio veiklas visada reikia bausti realiomis bausmėmis (77,6 proc.). Tik 12,9 proc. tyrimo dalyvių pateisina korupciją, kaip problemos sprendimo būdą. Palyginus 2018 m. ir 2020 m. tyrimo dalyvių nuomones, galima teigti, kad požiūrio dinamika iš dalies teigiama ir vis daugiau gyventojų suvokia korupcijos grèsmę bei žalą. İvertinus visus tirtus teiginius, nustatyta, kad didesnė dalis jiems pritaria, mažesnè dalis visiškai su jais nesutinka. Tikslinga pastebèti, kad visgi 8,7 proc. padidejjo dalis pateisinančiųjų korupciją kaip galimą problemos sprendimo būdą.

1 lentelè. Respondentų sutikimo su teiginiais, apibūdinančiais korupcijos reiškinị, pasiskirstymas 2018 m. ir 2020 m. (proc.)

\begin{tabular}{|c|c|c|c|c|c|c|c|}
\hline \multirow[b]{2}{*}{$\begin{array}{l}\text { Eil. } \\
\text { Nr. }\end{array}$} & \multirow[b]{2}{*}{ Korupcijos apibūdinimas } & \multicolumn{3}{|c|}{2018} & \multicolumn{3}{|c|}{2020} \\
\hline & & Sutinku & $\begin{array}{l}\text { Iš dalies } \\
\text { sutinku }\end{array}$ & $\begin{array}{l}\text { Nesu- } \\
\text { tinku }\end{array}$ & Sutinku & $\begin{array}{l}\text { Iš dalies } \\
\text { sutinku }\end{array}$ & $\begin{array}{l}\text { Nesu- } \\
\text { tinku }\end{array}$ \\
\hline 1. & $\begin{array}{l}\text { Korupcinio pobūdžio veiklos yra nusikaltimai, } \\
\text { už kuriuos visada reikia bausti realiomis } \\
\text { bausmemis }\end{array}$ & 71,0 & 23,9 & 5,2 & 77,6 & 20,7 & 1,7 \\
\hline 2. & $\begin{array}{l}\text { Korupcija pažeidžia žmogaus teises, iškreipia } \\
\text { socialinị teisingumą, žaloja visuomenės moralę }\end{array}$ & 83,9 & 14,2 & 1,9 & 84,5 & 15,5 & 0 \\
\hline 3. & $\begin{array}{l}\text { Korupcija iškreipia sažziningą konkurenciją, } \\
\text { verslo sąlygas, mažina ekonomikos augimą }\end{array}$ & 80,6 & $14,4 \%$ & 1,9 & 86,2 & 13,8 & 0 \\
\hline 4. & $\begin{array}{l}\text { Korupcija kelia grèsmę demokratijai ir teisinei } \\
\text { valstybei, valstybès valdymui }\end{array}$ & 83,2 & 16,1 & 0,6 & 82,8 & 17,2 & 0 \\
\hline 5. & $\begin{array}{l}\text { Korupcija pateisinama, nes žmogui sunku } \\
\text { surasti kitų problemų sprendimo būdų }\end{array}$ & 7,1 & 18,7 & 74,2 & 12,9 & 21,6 & 65,5 \\
\hline
\end{tabular}


Tyrimo dalyvių prašyta pateikti požiūrị i korupcijos paplitimą rajone (1 pav.).

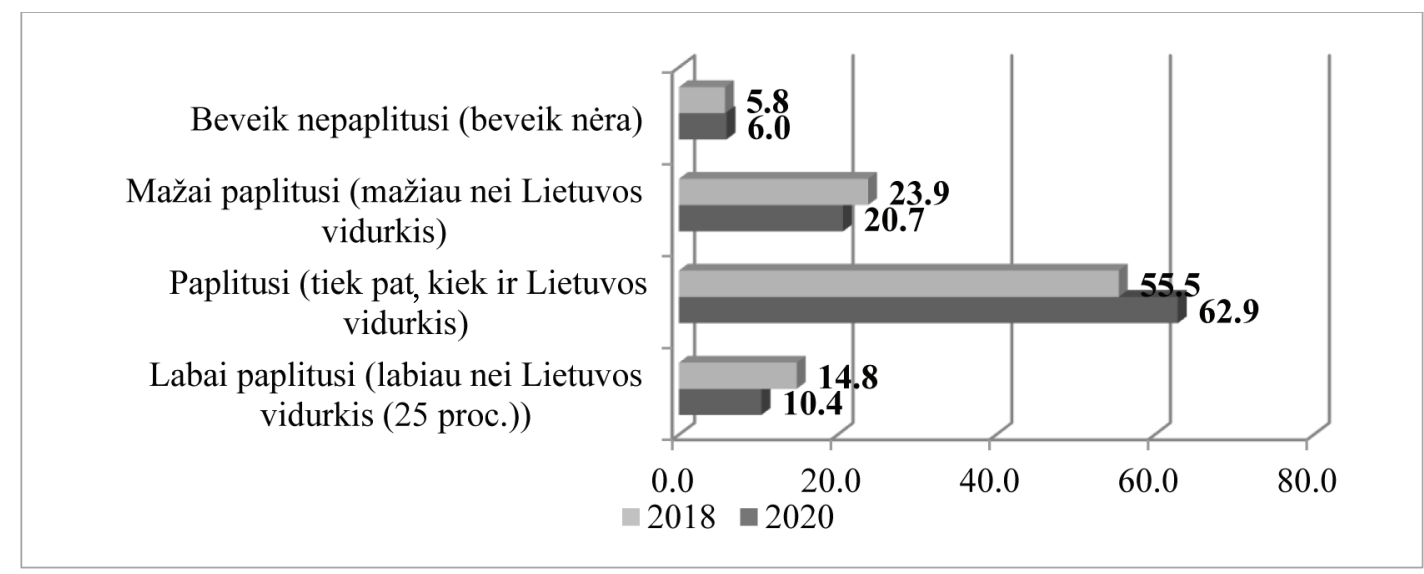

1 pav. Respondentų atsakymų i klausimą, kiek korupcija paplitusi Klaipėdos rajone, palyginimas 2018 m. ir 2020 m. (proc.)

62,9 proc. apklaustujų mano, kad šis neigiamas reiškinys rajone paplitęs tiek pat, kiek ir visoje Lietuvoje (1 pav.); 20,7 proc. - kad korupcijos paplitimas Klaipėdos rajone mažesnis nei Lietuvoje, 10,4 proc. - korupcija jų gyvenamojoje teritorijoje yra labiau paplitusi nei Lietuvoje. Palyginus $2018 \mathrm{~m}$. ir $2020 \mathrm{~m}$. duomenis nustatyta, kad 7,4 proc. padidejo dalis manančiųų, jog korupcijos paplitimas rajone ir Lietuvoje yra vienodas. Teigiamą pokytị atskleidžia tai, kad 4,4 proc. sumažèjo dalis manančiųjų, jog korupcija Klaipėdos rajone labiau paplitusi nei visoje Lietuvoje.

Dažniausia respondentai įvardijo šias tris pagrindines korupcijos paplitimo priežastis ( 2 pav.): visuomenès aktyvumo stoka (59,5 proc.), per didelis biurokratizmas (53,4 proc.), visuomenès ịpročiai (44 proc.). Tyrimo rezultatai atskleidè, kad respondentai suvokia visuomenès atsakomybę mažinant korupcijos mastą. Kitos respondentų įvardytos priežastys: netinkamai parinkti kontrolieriai, jų sėslumas, politika. Mažiausiai pritarimo sulaukẻ teiginiai dèl valstybės tarnautojų ir pareigūnų per didelių galių (37,1 proc.) ir per mažų atlyginimų (34,5). Palyginus, kaip pasiskirste atsakymai pagal amžių, statistiškai reikšmingų skirtumų nenustatyta. Skirtingoms priežastims labiau pritarẻ skirtingų amžiaus grupių respondentai, vis dèlto dažniausia atsakymo variantą taip rinkosi 30-40-mečiai.

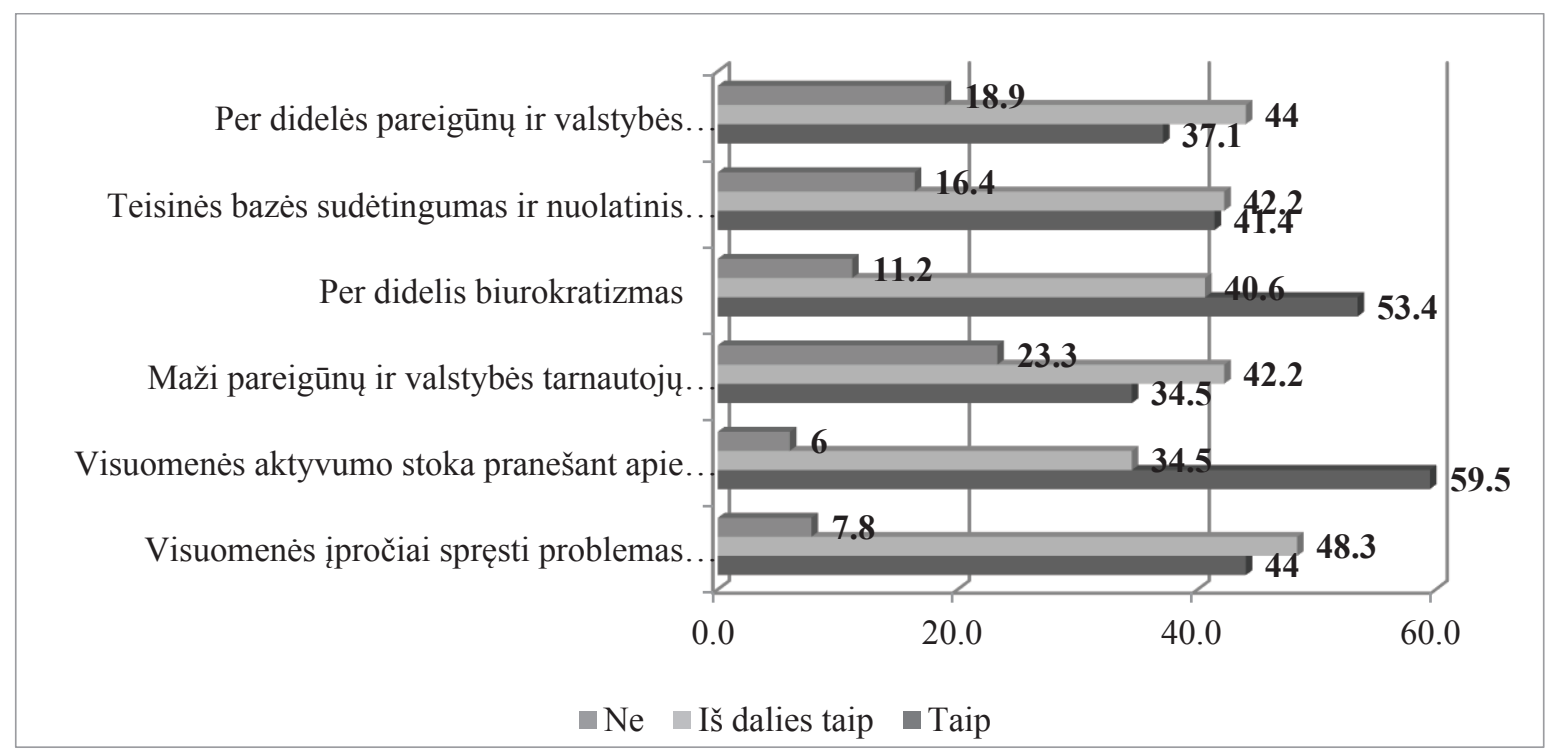

2 pav. Respondentų atsakymų i klausimą, kokie veiksniai yra korupcijos paplitimo Klaipėdos rajone priežastys, pasiskirstymas (proc.) 
Tyrimo dalyvių požiūris ị subjektus, skatinančius korupcijos paplitimą Klaipėdos rajone, pateiktas 3 paveiksle. Jie įvardijo, kad korupcijos paplitimui Klaipèdos rajone didžiausią ịtaką daro politikai (61,2 proc.), verslininkai (49,1 proc.), gyventojai (37,9 proc.). Visi subjektai, anot respondentų, bent iš dalies prisideda prie korupcijos paplitimo rajone. Mažiausiai paplitimą lemia viešųų i̇staigų darbuotojai (nedaro - 25 proc.) ir teisésaugos institucijos (nedaro - 20,7 proc.). Palyginus, kaip pasiskirste atsakymai pagal amžių, statistiškai reikšmingų skirtumų nenustatyta. Skirtingiems subjektams daromai ịtakai labiau pritare jauniausios grupės respondentai (18-29 m.), iš dalies daromai įtakai pritarė vyriausios grupès tyrimo dalyviai (52 m. ir vyresni).

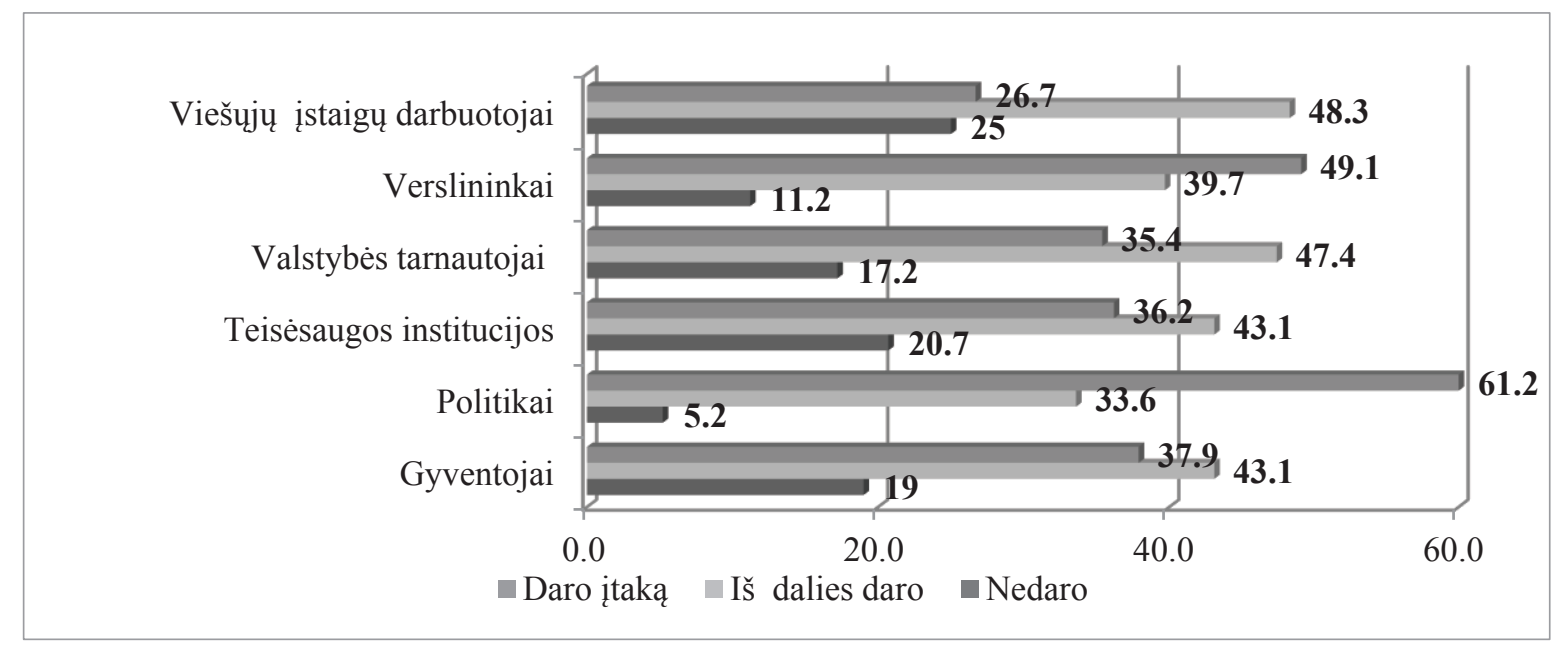

3 pav. Respondentų atsakymų ị klausimą, kas lemia korupcijos paplitimą Klaipedos rajone, pasiskirstymas (proc.)

Tyrimo dalyvių nuomonių dėl korupcijos paplitimo Klaipėdos rajono institucijose dinamika pateikta 2 lentelèje. Galima skirti įstaigas, kuriose, respondentų nuomone, korupcija yra paplitusi, tai: medicinos įstaigos (taip - 62,1 proc.), teismas (taip - 35,3 proc.), žemètvarka (taip - 35,3 proc.). Respondentų požiūriu, mažiausiai korupcija paplitusi „Sodroje“ (ne - 57,8 proc.), Mokesčių inspekcijoje (ne - 45,7 proc.), švietimo i̊staigose (ne $-43,1$ proc.).

2 lentelè. Respondentų atsakymų i klausimą, kuriose Klaipèdos rajono institucijose korupcija paplitusi, pasiskirstymas, proc.

\begin{tabular}{|c|l|c|c|c|c|c|c|}
\hline \multirow{2}{*}{$\begin{array}{c}\text { Eil. } \\
\text { Nr. }\end{array}$} & \multicolumn{2}{|c|}{ Atsakymo variantas } & \multicolumn{3}{c|}{$\mathbf{2 0 2 0}$} & \multicolumn{3}{c|}{} \\
\cline { 2 - 8 } & & Taip & Iš dalies & Ne & Taip & Iš dalies & Ne \\
\hline 1. & Aplinkos apsauga & 22,6 & 39,3 & 38,1 & 32,8 & 39,7 & 27,5 \\
\hline 2. & Medicinos i̇staigos & $\mathbf{5 3 , 5}$ & 31,6 & 14,9 & $\mathbf{6 2 , 1}$ & 34,5 & 3,4 \\
\hline 3. & Mokesčių inspekcija & 20,6 & 27,7 & $\mathbf{5 1 , 7}$ & 15,5 & 38,8 & $\mathbf{4 5 , 7}$ \\
\hline 4. & Policija & 15,5 & 39,4 & 45,1 & 17,3 & 40,5 & $\mathbf{4 2 , 2}$ \\
\hline 5. & Savivaldybės administracija, padaliniai & $\mathbf{4 5 , 8}$ & 31,6 & 22,6 & 33,6 & 44,0 & 22,4 \\
\hline 6. & „Sodra“ & 9,7 & 23,2 & $\mathbf{6 7 , 1}$ & 12,9 & 29,3 & $\mathbf{5 7 , 8}$ \\
\hline 7. & Spauda & 16,1 & 33,5 & $\mathbf{5 0 , 4}$ & 32,8 & 37,1 & 30,1 \\
\hline 8. & Švietimo įstaigos & 14,2 & 38,1 & 47,7 & 20,7 & 36,2 & $\mathbf{4 3 , 1}$ \\
\hline 9. & Teismas & 19,4 & 40,6 & 40 & $\mathbf{3 5 , 3}$ & 38,8 & 25,9 \\
\hline 10. & Verslo įmonės & $\mathbf{2 9 , 7}$ & 44,5 & 25,8 & 33,6 & 39,7 & 26,7 \\
\hline 11. & Žemètvarka & $\mathbf{3 6 , 8}$ & 34,8 & 28,4 & $\mathbf{3 5 , 3}$ & 37,1 & 27,6 \\
\hline
\end{tabular}


Analizuojant respondentų požiūrio ị korupcijos paplitimą rezultatus galima konstatuoti, kad $2020 \mathrm{~m}$. tyrimo dalyviai labiau nei $2018 \mathrm{~m}$. pritare tam, jog korupcija labiau paplitusi Klaipėdos rajono institucijose: pateiktame sąraše 8-iose institucijose nurodytas didesnis korupcijos paplitimas; 3-ose įstaigose - mažesnis. Labiausiai išaugo nuomonių dèl korupcijos paplitimo teisme $(+15,9$ proc.) ir spaudoje $(+16,7$ proc.) procentas. Didžiausia neigiama dinamika išryškèjo vertinant korupcijos paplitimą savivaldybės administracijos padaliniuose (-12,2 proc.). Taip galëjo atsitikti dèl to, kad dalị 2020 metų daugelis viešojo administravimo ir viešųų įstaigų dirbo bei paslaugas gyventojams teiké nuotoliniu, e. būdu. Daugeliui gyventojų, ịpratusių klausimus spręsti tiesiogiai, nuotolinis paslaugų teikimas asocijuojasi su kliūtimis, trikdžiais ir biurokratija, galima korupcija. Apskritai gana reikšmingi judejjimo ir kontaktų ribojimai neigiamai veikia žmoniu pasitikejjimą, kuria barjero ir atskirties jausmą. Požiūrio ị teismus neigiamą dinamiką galima paaiškinti metu pradžioje nuvilnijusiu skandalu dèl pradètų tyrimų prieš teisèjus, teisètvarkos sistemos problemų viešinimu. Palyginus, kaip pasiskirstė atsakymai amžiaus aspektu, nustatyti statistiškai reikšmingi skirtumai dviejų teiginių atvejais: $30-40 \mathrm{~m}$. tyrimo dalyviai mano, kad korupcija labiau paplitusi aplinkos apsaugoje ir savivaldybès administracijoje. Pastebėtina, kad šios amžiaus grupès respondentai dažniau įvardydavo ir kitas įstaigas bei akcentuodavo korupcijos paplitimą.

\section{Klaipėdos rajono gyventojų kyšio davimo patirties kaitos apžvalga}

Respondentų atsakymų i klausimą, ar jums teko duoti kyṣ̨̌ Klaipėdos rajone, 2018-2020 m. palyginimas pateiktas 3 lentelèje. Daugiausia tyrimo dalyvių nurodẻ davę kyšius medicinos darbuotojams (32,8 proc.), valstybės tarnautojams (11,2 proc.), politikams (6,9 proc.). Atsakymo variante kita respondentai nurodé / pateikè paaiškinimus: „Medicinos srityje daktarai kartais akivaizdžiai parodo, kad nori pinigų už tam tikrą apžiūrą ar siuntimą, tačiau korupcija neišnyks, kol žmonès patys kiš tuos pinigus, ypač vyresnès kartos atstovai; ne Klaipėdos rajone, bet Klaipėdoje (Klaipėdos rajone gyvenantys asmenys kreipiasi ir ị Klaipėdos miesto įstaigas); niekada nesu davęs jokio kyšio, labai esu prieš tai.“ Išanalizavus 2018-2020 m. dinamiką galima konstatuoti neryškų padidejjimą ties 1-3 atsakymo variantais ir neryškų sumažèjimą 4-5 atsakymų variantų atvejais. Komentuojant šią dinamiką galima daryti prielaidą, kad Klaipėdos rajono gyventojams (kaip ir visos Lietuvos) karantino laikotarpiu buvo sunkiau patekti ị sveikatos priežiūros įstaigas, kai kurios paslaugos (pvz., odontologo, ortodonto) iš viso buvo neprieinamos. Tokia situacija galëjo skatinti asmenis siūlyti / duoti kyšius susitikus arba siekiant susitikti su gydytoju.

3 lentelè. Respondentų atsakymų ị klausimą, ar Klaipẻdos rajone teko duoti kyšị, palyginimas $2018 \mathrm{~m}$. ir $2020 \mathrm{~m}$. (proc.)

\begin{tabular}{|c|l|c|c|c|c|}
\hline Eil. & \multicolumn{2}{|c|}{ Atsakymo variantas } & \multicolumn{2}{|c|}{$\mathbf{2 0 1 8}$} & \multicolumn{2}{c|}{2020} \\
\cline { 3 - 6 } Nr. & & Taip & Ne & Taip & Ne \\
\hline 1. & Medicinos darbuotojui & 29,6 & 70,4 & 32,8 & 67,2 \\
\hline 2. & Pareigūnui & 3,2 & 96,8 & 4,3 & 95,7 \\
\hline 3. & Politikui & 3,2 & 96,8 & 6,9 & 93,1 \\
\hline 4. & Valstybės tarnautojui & 12,3 & 87,7 & 11,2 & 88,8 \\
\hline 5. & Verslininkui & 5,8 & 94,2 & 3,4 & 96,6 \\
\hline
\end{tabular}

4 lentelèje pateiktas respondentų atsakymų, kuriems Klaipėdos rajono savivaldybės padalinių, ịstaigų ar institucijų darbuotojams jie yra davę kyšį, pasiskirstymas 2018 m. ir 2020 m. 
4 lentelè. Respondentų atsakymų ị klausimą, ar esate davęs kyši šių Klaipėdos rajono savivaldybės padalinių, ịstaigų ar institucijų darbuotojams, pasiskirstymo palyginimas 2018 m. ir $2020 \mathrm{~m}$. (proc.)

\begin{tabular}{|c|l|c|c|}
\hline $\begin{array}{c}\text { Eil. } \\
\text { Nr. }\end{array}$ & \multicolumn{1}{|c|}{ Atsakymo variantas } & $\mathbf{2 0 1 8}$ & $\mathbf{2 0 2 0}$ \\
\hline 1. & Atliekų tvarkymas & 0 & 1,7 \\
\hline 2. & Klaipėdos rajono apylinkès teismas & 0,6 & 2,6 \\
\hline 3. & Klaipėdos rajono policijos komisariatas & 0 & 2,6 \\
\hline 4. & Klaipėdos rajono savivaldybės administracija & 5,8 & 6,0 \\
\hline 5. & Klaipėdos rajono žemėtvarkos skyrius & 3,9 & 3,4 \\
\hline 6. & Lopšelis-darželis & 2,6 & 7,8 \\
\hline 7. & Medicinos istaiga & 28,4 & 30,2 \\
\hline 8. & Mokykla & 2,6 & 6,0 \\
\hline 9. & $\begin{array}{l}\text { Klaipėdos teritorijų planavimo ir statybos valstybinės priežiūros skyrius, Statybos } \\
\text { valstybinès priežiūros Gargždų poskyris }\end{array}$ & 3,9 & 4,3 \\
\hline
\end{tabular}

Daugelyje atsakymo variantų tyrimo dalyviai nurodẻ kiek dažniau davę kyšius. Didžiausias padidėjimas įvardijant lopšelį-darželi ( $+5,2$ proc.), mažiausias - savivaldybės administraciją ( $+0,2$ proc.); sumažejimas ìvardijant žemėtvarkos skyrių $(-0,5)$. Atsakymo variante kita tyrimo dalyviai įvardijo: „Duota Klaipedos mieste, ne rajone; kyšių neduodu, geriau nukenčiu." Palyginus, kaip pasiskirstė atsakymai amžiaus aspektu, statistiškai reikšmingų skirtumų nenustatyta. Teigiamas faktas, kad jauniausios amžiaus grupès respondentai ịvardijo tik vieną ịstaigų grupę, kur jie davė kyšị (medicinos ịstaiga - 14,3 proc.). Kitų amžiaus grupių respondentai dažniau įvardydavo davę kyšius įvairių Klaipedos rajono įstaigų ir padalinių darbuotojams.

Respondentų prašyta nurodyti duoto kyšio formą (5 lentelè). Dažniausia minèti pinigai (28,4 proc.), maisto produktai (17,2 proc.), atsilyginimas paslaugomis (14,7 proc.). Analizuojant kyšių davimo formų 2018-2020 m. dinamiką galima pastebèti, kad respondentai nurode dažniau davę kyšius ịvairiomis formomis (padidejimas yra nuo 1,33 iki 2,26 karto). Didžiausias padidejimas - kaip kyši siūlant kitas paslaugas (2,26 karto). Kaip jau komentuota, tokia neigiama dinamika gali būti siejama su esama ịtempta situacija dèl viruso ir didesniu klientų skaičiaus ribojimu.

5 lentelè. Respondentų nurodytų kyšio davimo formų palyginimas 2018 m. ir 2020 m. (proc.)

\begin{tabular}{|c|l|c|c|}
\hline $\begin{array}{c}\text { Eil. } \\
\text { Nr. }\end{array}$ & \multicolumn{1}{|c|}{ Atsakymo variantas } & $\mathbf{2 0 1 8}$ & $\mathbf{2 0 2 0}$ \\
\hline 1. & Pinigais & 21,3 & 28,4 \\
\hline 2. & Maisto produktais & 9 & 17,2 \\
\hline 3. & Daiktais & 4,5 & 6,0 \\
\hline 4. & Paslaugomis & 6,5 & 14,7 \\
\hline 5. & Atsilyginta kitaip & 2,6 & 4,3 \\
\hline
\end{tabular}

Respondentų atsakymų i klausimą, kokiomis aplinkybėmis priẻmète sprendimą duoti kyšị, procentinis pasiskirstymas ir rezultatų palyginimas $2018 \mathrm{~m}$. ir $2020 \mathrm{~m}$. pateiktas 6 lentelëje. Kadangi buvo galima nurodyti kelis atsakymo variantus, bendra suma yra didesnè nei 100 proc. Aiškindami aplinkybes, respondentai dažniausia nurodė patys nusprendę duoti kyši (20,7 proc.), gavę užuominą (16,4 proc.), girdèję iš kitų (16,4 proc.). Analizuojant kyšių davimo aplinkybių dinamiką galima konstatuoti, kad respondentai rečiau girdi tiesioginius nurodymus ar kitų rekomendacijas duoti kyšį, tačiau dažniau pastebi užuominas apie kyšio davimą arba tokị sprendimą priima patys.

Apskritai galima konstatuoti teigiamus pokyčius: gyventojai mažiau bepastebi užuominų apie kyšio davimą, mažiau apie tai girdi ir iš kitų, tačiau dažniau apsisprendžia patys jị duoti. Kaip minèta, karantino ir nuotolinio darbo laikotarpiu žmonės dažnai abejojo, kad nuotoliniu būdu jiems pavyks išspręsti savo problemą, o patekimą pas specialistą vertino kaip išskirtinę situaciją, tad patys apsispręsdavo duoti kyšị. 
6 lentelè. Respondentų nurodytų kyšio davimo aplinkybių palyginimas 2018 m. ir 2020 m. (proc.)

\begin{tabular}{|c|l|c|c|}
\hline $\begin{array}{c}\text { Eil. } \\
\text { Nr. }\end{array}$ & \multicolumn{1}{|c|}{ Atsakymo variantas } & $\mathbf{2 0 1 8}$ & $\mathbf{2 0 2 0}$ \\
\hline 1. & Kyšio nedaviau & 65,2 & 61,2 \\
\hline 2. & Tiesiogiai paprašyta & 5,2 & 1,7 \\
\hline 3. & Girdèjau iš kitų, kad reikia duoti & 19,4 & 16,4 \\
\hline 4. & Užsiminta & 12,3 & 16,4 \\
\hline 5. & Nusprendžiau pats & 16,8 & 20,7 \\
\hline
\end{tabular}

4 paveiksle pateiktas respondentų atsakymų, ar ateityje jie duotų kyšį, kad išspręstų problemą, pasiskirstymas 2018 ir 2020 metais.

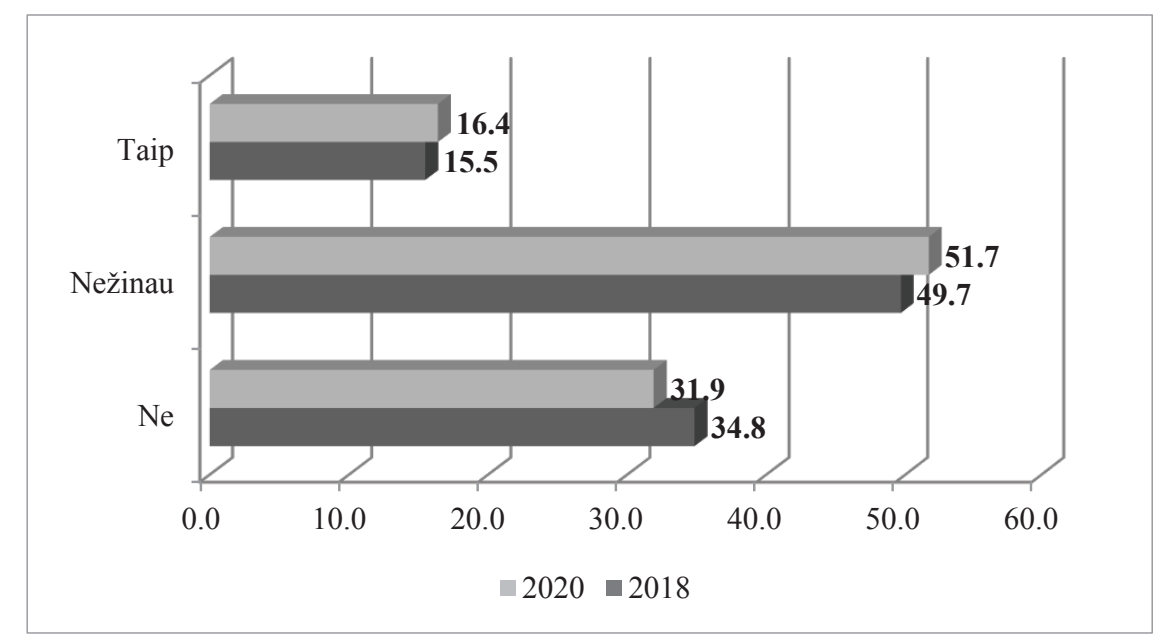

4 pav. Respondentų atsakymų ị klausimą, ar ateityje duotų kyši, kad išspręstų problemą, pasiskirstymas $2018 \mathrm{~m}$. ir $2020 \mathrm{~m}$. (proc.)

Tenka pastebėti, kad ir šiuo klausimu respondentai pademonstravo prastejjančią situaciją: $2020 \mathrm{~m}$. 0,9 proc. daugiau respondentų nurode ketinantys ir ateityje duoti kyšį, kad išspręstų problemą; dviem procentais daugiau žmonių nurodè nežinantys, kaip apsispręstų (abejoja, ar duotų kyši ); 2,9 proc. mažiau apklaustujų teigia, kad iš viso neduotų kyšio, kad išspręstų problemą.

\section{Išvados}

1. Ištirta, kad apskritai Klaipėdos rajono gyventojai neigiamai vertina korupcijos reiškinį. Daugiau nei keturi penktadaliai tyrimo dalyvių sutinka, kad korupcija iškreipia sąžiningą konkurenciją, verslo sąlygas, mažina ekonomikos augimą, be to, pažeidžia žmogaus teises, iškreipia socialinį teisingumą ir žaloja visuomenès moralę. Kiek mažiau tyrimo dalyvių sutiko su tuo, kad už korupcinio pobūdžio veiklas visada reikia bausti realiomis bausmèmis. Palyginus 2018 m. ir 2020 m. tyrimų rezultatus galima teigti, kad požiūrio dinamika yra teigiama: vis daugiau Klaipedos rajono gyventojų suvokia korupcijos grèsmę ir žalą. Bet padidèjo ir dalis pateisinančiujų korupciją kaip galimą problemos sprendimo būdą. Respondentų nuomone, šis neigiamas reiškinys Klaipėdos rajone paplitęs tiek pat, kiek ir visoje Lietuvoje. 2018 m. ir 2020 m. duomenų dinamika atskleidè, kad daugejja manančiųu, jog korupcija rajone ir Lietuvoje paplitusi vienodai; mažeja dalis manančiujų, kad korupcija Klaipėdos rajone paplitusi labiau nei visoje Lietuvoje. Daugiau nei pusė respondentų pritare dẻl šių pagrindinių korupcijos paplitimo priežasčių: visuomenès aktyvumo stoka, per didelis biurokratizmas, visuomenès ịpročiai. Tyrimo dalyvių teigimu, visi subjektai bent iš dalies prisideda prie korupcijos paplitimo rajone, vis dèlto didžiausią ịtaką daro politikai. 
2. Respondentų nuomone, korupcija labiausiai paplitusi: medicinos įstaigose, teisme, žemètvarkoje. $2020 \mathrm{~m}$. tyrimo dalyviai, palyginus su 2018 m., pritare tam, kad korupcija paplitusi Klaipédos rajono institucijose: pateiktame sąraše 8 institucijose nurodomas didesnis korupcijos paplitimas; 3 įstaigose - mažesnis. Labiausiai išaugo skaičius manančiųjų, kad korupcija paplitusi teisme ir spaudoje. Iš esmės sumažèjo korupcijos paplitimas savivaldybės administracijos padaliniuose. Tai galima būtų paaiškinti tuo, kad dali 2020 metų daugelis viešojo administravimo ir viešujų ịstaigų dirbo bei paslaugas gyventojams teikẻ nuotoliniu būdu. Klausimus tiesiogiai sprendžiantiems gyventojams nuotolinis paslaugų teikimas asocijuojasi su kliūtimis, trikdžiais ir biurokratija, galima korupcija. Analizuojant respondentų kyšių davimo patirtį nustatyta, kad daugiausia tyrimo dalyvių nurodè davę kyšius medicinos darbuotojams. Kituose atsakymų variantuose ryškejja tiek didèjimo, tiek ir mažejjimo tendencijos. Komentuojant šią dinamiką galima daryti prielaidą, kad Klaipedos rajono (kaip ir visos Lietuvos) gyventojams karantino laikotarpiu buvo sunkiau patekti ị sveikatos priežiūros ịstaigas, o kai kurios paslaugos buvo iš viso neprieinamos. Ši situacija galëjo skatinti asmenis siūlyti / duoti kyšius susitikus arba siekiant susitikti su gydytoju. Tyrimo dalyviai nurodẻ kiek dažniau davę kyšius ịvairiems subjektams. Teigiamas faktas, kad jauniausios amžiaus grupès respondentai ịvardijo tik vieną ịstaigų grupę (t. y. medicinos įstaigas), kur jie davè kyšị. Kaip pagrindinę kyšio davimo formą jie dažniausia nurodè pinigus. Analizuojant kyšiu davimo formų 2018-2020 m. dinamiką pastebėta, kad respondentai nurodè dažniau davę kyšius ịvairiomis formomis (padidèjimas - nuo 1,33 iki 2,26 karto). Didžiausias padidejjimas - kaip kyšį siūlant kitas paslaugas (2,26 karto). Aiškindami aplinkybes, respondentai dažniausia nurodè patys nusprendę duoti kyši. Apskritai galima konstatuoti teigiamus pokyčius: gyventojai mažiau pastebi esant užuominų dèl kyšio davimo, mažiau apie tai girdi ir iš kitų, tačiau dažniau patys apsisprendžia jị duoti. Kaip minèta, karantino ir nuotolinio darbo laikotarpiu žmonès dažnai abejoja, ar nuotoliniu būdu pavyks išspręsti savo problemą, o patekimą pas specialistą vertina kaip išskirtinę situaciją, tad patys apsisprendžia duoti kyšį. $2020 \mathrm{~m}$. daugiau respondentų nurodė ketinantys ir ateityje spręsdami problemas duoti kyšị.

\section{Literatūra}

„Transparency International“ Lietuvos skyrius. (2018). Savivaldybiu skaidrumo tyrimas. Prieiga internete: https://jurgiokepure.1t/tyrimas/2018.

Ackerman, R. S., Truex, R. (2012). Corruption and Policy Reform. Prieiga internete: http://ssrn.com/abstract=2007152

Ackerman, R. S. (2001). Korupcija ir valdžia: priežastys, padariniai ir reforma. Vilnius: Vaga.

Begovic, B. (2005). Corruption: Concepts, types, causes and consequences. Prieiga internete: https://www.researchgate.net/publication/265364211_Corruption_Concepts_types_causes_and_consequences

Bowman, D., Gilligan, G. (2007). Public Awareness of Corruption in Australia. Journal of Financial Crime, Vol. 14, Issue 4, p. 438-452.

Bryman, A. (2016). Social Research Methods. Oxford University Press.

Chakraborty, I., Maity, P. (2020). COVID-19 Outbreak: Migration, effects on society, global environment and prevention. Science of the Total Environment, Vol. 728, p. 1-7.

Dimant, E., Tosato, G. (2018). Causes and Effects of Corruption: What has Past Decade's Empirical Research Taught us? Journal of Economic Survey, Vol. 32, No. 2, p. 335-356.

Graycar, A., Sidebottom, A. (2012). Corruption and Control: A Corruption Reduction Approach. Journal of Financial Crime, Vol. 19, Issue 4, p. 384-399.

Iqbal, M. S., Seo, J. (2008). E-Governance as an Anti-Corruption Tool: Korean Cases. Journal of Korean Association for Districtal Information Society Cases, Vol. 6, p. 51-78.

Kardelis, K. (2009). Moksliniu tyrimu metodologija ir metodai. Šiauliai: Liucijus.

Kohler, J. C. (2011). Fighting corruption in the health sector: methods, tools, and good practices. New York: United Nations Development Programme.

Kohler, J. C., Dimancesco, D. (2020) The risk of corruption in public pharmaceutical procurement: how anti-corruption, transparency and accountability measures may reduce this risk. Global Health Action, 13: sup1, 1694745. Doi: 10.1080/16549716.2019.1694745

Kozłowski, A. J., Czaplicka Kozłowska, I. Z., Świrska, A. (2016). The Phenomenon of Corruption in Public Sector Organizations (Local Government Case Studies from the Warmia and Mazury Districts of Poland). Hyperion International Journal of Econophysics \& New Economydate, Vol. 9, Issue 1, p. 117-141. 
Lewis, J. (2017). Social impacts of corruption upon community resilience and poverty. Journal of Disaster Risk Studies, p. 1-8. Prieiga internete: https://www.researchgate.net/publication/315844126_Social_impacts_of_corruption_ upon_community_resilience_and_poverty

Lietuvos korupcijos žemélapis 2020. (2021). Prieiga internete: https://www.stt.lt/analitine-antikorupcine-zvalgyba/lietuvos-korupcijos-zemelapis/7437

Lietuvos korupcijos žemèlapis. (2018). Prieiga internete: https://www.stt.lt/lt/menu/tyrimai-ir-analizes/

Lietuvos Respublikos Korupcijos prevencijos įstatymas. (2002). Gegužès 28 d., Nr. IX-904. Prieiga internete: https://eseimas.lrs.lt/portal/legalAct/lt/TAD/TAIS.168154/TpCkHJjwjX

Lietuvos Respublikos Seimo nutarimas „Dèl Lietuvos Respublikos nacionalinès kovos su korupcija 2015 -2025 metu programos patvirtinimo“. (2015). Kovo 10 d., Nr. XII-1537. Prieiga internete: https:// https://e-seimas.lrs.lt/portal/ legalAct/lt/TAD/8e499812cbbe11e49bcec506eeda6c5f

Lietuvos Respublikos specialiujų tyrimų tarnyba (STT). (2018). Veiklos ataskaita. Prieiga internete: https://www.stt.lt/ data/public/uploads/2021/01/stt_2018_m_veiklos_ataskaita.pdf

Mackey, T. K., Vian, T., Kohler, J. (2018). The sustainable development goals as a framework to combat health sector corruption. Bull World health Organ, Vol. 96 (9), p. 634-643.

Oficialios statistikos portalas. (2021). Gyventojai. Prieiga internete: https://osp.stat.gov.lt/gyventojai1

Pallant, J. (2016). SPSS Survival Manual. Allen \& Unwin, Sydney.

Šimanskiene, L., Paužuolienė, J., Staškevičius, A. (2020). Changes in society during COVID-19 pandemic: from point of view of health care workers. Journal of Modern Science, Vol. 2(45), p. 227-240.

Slamkov, G., Bilalli-Zendeli, A. (2016). Prevention of corruption - improving the efficiency in the monitoring of the assets. Vizione, Vol. 25, p. 183-190.

Transparancy international. (2021a). What is Corruption. Prieiga internete: https://www.transparency.org/en/what-iscorruption

Transparency International. (2020). Korupcijos suvokimo indeksas. Prieiga internete: https://www.transparency.lt/korupcijos-suvokimo-indeksas-ksi/

Transparency International. (2021). Anti-Corruption Glossary. Prieiga internete: https://www.transparency.org/glossary/term/corruption

United Nations Office of Drugs and Crime. (2020). Advisory Note: COVID-19 and Corruption in the Pacific. Prieiga internete: https:/www.pacific.undp.org/ content/pacific/en/home/library/eg/covid19-and-corruption-in-the-pacific.html

World Justice Project. (2021). Corruption and the COVID-19 Pandemic. Prieiga internete: https://worldjusticeproject.org/

\title{
THE CHANGE IN PERCEPTION AND EXPERIENCE OF CORRUPTION OF KLAIPEDDA DISTRICT RESIDENTS IN THE CONTEXT OF THE PANDEMIC
}

\author{
Ilvija Pikturnaité, Jurgita Paužuoliené, Robertas Kavolius \\ Klaipeda State University of Applied Sciences (Lithuania)
}

\section{Summary}

The global pandemic requires urgent decisions by governments to purchase goods without complying with public procurement laws and even negotiating their price, and to fight for hard-to-access resources (medical devices and equipment, health system workers). Meanwhile, many mechanisms for preventing and enforcing corruption are suspended due to the state of emergency. Such situations create opportunities for new forms of corruption, and for corrupt individuals to use the situation by bribing and receiving bribes, concluding agreements at unreasonable prices, using an official position to receive medical assistance or vaccinations, demanding payment for public and already paid-for services, plundering support, etc. 
National statistical information sources have identified slight positive developments in the anti-corruption environment over long periods of time. However, in 2020, according to the data of the Lithuanian Corruption Map, citizens notice more corruption, and tend to take illegal corrupt actions to solve their problems themselves. Citizens often come into contact with local municipalities in their day-to-day affairs, so the legitimate and transparent activities of local authorities are directly linked to individuals' corrupt practices and attitudes towards corruption. Thus, it makes sense to monitor the corrupt situation in a particular municipality. Therefore, this article presents continuous research into the perception and experience of corruption of residents carried out in the Klaipeda district authority. A repeat survey, which was carried out in the Klaipeda district authority in 2016, 2018 and 2020, allows us to assess the change in the perception and experience of corruption among the population.

The aim of the research is to assess the attitudes of Klaipeda district residents to corruption, and the change in the experience of corruption in the context of the pandemic. The research was implemented using a pre-prepared standardised questionnaire. A total of 116 respondents participated in the survey in 2020.

It was investigated that, in general, Klaipeda district residents take a negative view of the phenomenon of corruption. More than four-fifths of participants in the study agree that corruption distorts fair competition and business conditions, reduces economic growth, violates human rights, distorts social justice, and damages public morale. Comparing the results of the 2018 and 2020 surveys, it can be said that the dynamics of attitudes are positive: more and more residents of the Klaipeda district are aware of the threat and harm of corruption. However, there has also been an increase in the proportion of people justifying corruption as a possible solution to the problem. The survey has revealed that, in the opinion of the respondents, this negative phenomenon is as common in the Klaipeda district as in all of Lithuania. More than half of the respondents reported the following main reasons for the spread of corruption: lack of public activity, excessive bureaucracy, and societal habits. The participants in the study identified that all actors contribute at least in part to the spread of corruption in the area, and politicians have the most influence.

According to the respondents, corruption is most common: in medical institutions, in courts, in land use. In 2020, the participants in the survey tended more to agree that corruption is prevalent in Klaipeda district institutions than in 2018: the list presented indicates a higher prevalence of corruption in eight institutions, and lower in three institutions. The opinion on the prevalence of corruption in court and in the press increased the most. This dynamic may be due to the fact that for part of 2020, many public administrative and public bodies worked and provided services to the population remotely. The remote provision of services for residents is associated with obstacles, disruption and bureaucracy, and possible corruption. The negative dynamics of attitudes towards the courts can be explained by the scandal about investigations of judges, and the publicity given to problems in the system of law and order at the beginning of 2020. Most participants reported giving bribes to medical staff. Commenting on these dynamics, it can be assumed that during the lockdown period, it was difficult to access health care institutions, and some services were not available at all. This situation may have encouraged individuals to offer/give bribes when meeting or in order to meet with a doctor. Participants in the study reported slightly more frequent bribes to various entities. As a basic form of bribe giving, respondents usually named money. In analysing the dynamics of bribegiving forms in 2018 to 2020, it was noticed that all forms of bribes increased from 1.33 to 2.26 times. The biggest increase was in offering other services as a bribe (2.26 times). Residents noticed less hints about a bribe request, less hear about it from others, but more often decide to give a bribe themselves. In 2020, more respondents indicated their intention to give a bribe in the future to solve problems.

KEY WORDS: corruption, local governance, prevention of corruption, citizens'attitudes.

JEL CODIES: D73, H79, K40.

Received: 2021-03-06

Revised: 2021-04-28

Accepted: 2021-05-04 